\title{
ANALISIS FAKTOR-FAKTOR YANG MEMPENGARUHI KINERJA BAITUL MAAL WAT TAMWIL (BMT) KHAIRU UMMAH LEUWILIANG
}

\section{ANALYSIS OF FACTORS THAT INFLUENCE THE PERFORMANCE OF BAITUL MAAL WAT TAMWIL (BMT) KHAIRU UMMAH LEUWILIANG}

\author{
R.M. Andriani19; K. Nawawi² \\ 1aProgram Studi Ekonomi Syariah Fakultas Agama Islam Universitas Ibn Khaldun, Jalan \\ KH Sholeh Iskandar KM.2, Kedung Badak, Tanah Sereal, Jawa Barat 16162, e-mail: \\ mitaandriani14@gmail.com \\ 2Program Studi Ekonomi Syariah Fakultas Agama Islam Universitas Ibn Khaldun, Jalan \\ KH Sholeh Iskandar KM.2, Kedung Badak, Tanah Sereal, Jawa Barat 16162, e-mail: \\ kholil@fai.uika-bogor.ac.id
}

\begin{abstract}
The purpose of this study is to determine the factors that affect the performance of BMT Khairu Ummah. This research is a field research with quantitative approach. There are several factors that affect the performance of BMT namely education, working hours, management, employee salaries, and product attributes. In addition, to measure the performance of BMT researchers using analysis of the report keuaangan. To analyze and test the hypothesis using multiple linear regression test with the help of SPSS 23.0 for window software. This research was conducted from February to March 2018. A total of 27 employees were taken as respondents with sampling technique. The results showed that there are four main factors that affect the performance of BMT namely education, management, employee salaries, and product attributes. Other factors that are estimated at the beginning like working hours did not significantly affect the performance of BMT Khairu Ummah Leuwiliang.
\end{abstract}

Keywords: Factors of perfomance, BMT Khairu Ummah Leuwiliang

\begin{abstract}
ABSTRAK
Tujuan dari penelitian ini adalah untuk mengetahui faktor-faktor yang mempengaruhi kinerja BMT Khairu Ummah. Penelitian ini merupakan penelitian lapangan dengan pendekatan kuantitatif. Ada beberapa faktor yang mempengaruhi kinerja BMT yaitu pendidikan, jam kerja, manajemen, gaji karyawan, dan atribut produk. Selain itu, untuk mengukur kinerja BMT peneliti menggunakan analisis laporan keuangan. Untuk analisis dan uji hipotesis menggunakan uji regresi linear berganda dengan bantuan software SPSS 23.0 for window. Penelitian ini dilakukan dari bulan februari sampai dengan maret 2018. Sebanyak 27 karyawan yang diambil sebagai responden dengan pengambilan teknik sampel. Hasil penelitian menunjukkan bahwa ada empat faktor utama yang mempengaruhi kinerja BMT yaitu pendidikan, manajemen, gaji karyawan, dan atribut produk. Faktor lain yang diperkirakan diawal seperti jam kerja ternyata tidak berpengaruh secara signifikan terhadap kinerja BMT Khairu Ummah Leuwiliang.
\end{abstract}

Kata Kunci: Faktor-Faktor kinerja, BMT Khairu Ummah Leuwiliang 
Andriani, Raden Mita. 2018. Analisis Faktor-Faktor yang Mempengaruhi Kinerja Baitul Maal Wat Tamwil (BMT) Khairu Ummah Leuwiliang. Jurnal Syarikah 4 (1): 9-21.

\section{PENDAHULUAN}

Pada hakikatnya kemiskinan timbul bukan dikarenakan tidak adanya keterampilan, tetapi karena terkendalanya ketersediaan modal yang cukup. Karena untuk meningkatkan produktivitas, ketersediaan modal yang cukup merupakan salahsatu faktor penunjang yang penting. Pada umumnya hal ini menjadi masalah bagi masyarakat kecil. Keadaan mereka yang unbankable menutup jalan mereka untuk memperoleh modal melalui akses bank, itu karena bank berpegang pada asas bankable dalam memutuskan kreditnya.

Maka tidak heran jika mereka lebih memilih untuk memperoleh dana dengan akses mudah melalui rentenir, walau mereka harus menanggung suku bunga yang sangat tinggi yang kemungkinan dalam waktu tertentu dapat mematikan usahanya. Sehingga pada kenyataannya, jasa kredit informal (rentenir) tidak mampu meningkatkan kesejahteraan masyarakat. Jasa kredit informal ini umumnya hanya bersifat jangka pendek, akibatnya tidak mampu menciptakan akumulasi permodalan. Pelayanan kredit tersebut hanya sekedar untuk membantu mempertahankan kehidupan, tetapi tidak mampu meningkatkan standar kehidupan dan kesejahteraan penerima kredit secara nyata, bahkan tidak sedikit yang mengalami kemiskinan. Atau dengan kata lain, jasa kredit informal ini dapat berdampak sebagai pola kemiskinan yang baru (Ridwan, 2004:26-27).

Kemiskinan tidak hanya dapat dituntaskan oleh pemerintah, akan tetapi menjadi tanggungjawab bersama berbagai pihak, baik pemerintah, lembaga swasta, lembaga profesi, perguruan tinggi maupun masyarakat itu sendiri. Permasalahan kemiskinan tersebut jika tidak diantisipasi, maka akan membawa dampak yang buruk seperti menurunnya kualitas sumber daya manusia, timbulnya kecemburuan sosial, pengangguran, kerentanan, kriminalitas dan berbagai dampak negatif lainnya (Sriyana, 2013:29-50). Oleh karena itu, perlu dilakukan upaya dan langkah konkrit untuk menanggulanginya, salah satunya dengan keberadaan lembaga keuangan syariah. Tujuan dari berdirinya lembaga tersebut untuk meningkatkan kualitas kehidupan sosial ekonomi masyarakat, sehingga dapat mengurangi kesenjangan sosial ekonomi.

Salah satu lembaga keuangan syariah adalah Baitul Maal wat Tamwil (BMT). Keberadaan BMT dalam menjalankan aktifitasnya memiliki dua fungsi utama, yaitu sebagai lembaga yang menyalurkan harta-harta ibadah seperti zakat, infak, sedekah dan wakaf, serta dapat pula berfungsi sebagai institusi yang bergerak di bidang investasi yang bersifat produktif sebagaimana layaknya bank. Pada fungsi kedua ini dapat dipahami bahwa selain berfungsi sebagai lembaga keuangan, BMT juga berfungsi sebagai lembaga ekonomi. Sebagai lembaga keuangan, BMT bertugas menghimpun dana dari masyarakat (anggota BMT) yang mempercayakan dananya disimpan di BMT dan menyalurkan dana kepada masyarakat (anggota BMT) yang diberikan pinjaman oleh BMT. Sedangkan sebagai lembaga ekonomi, BMT berhak melakukan kegiatan ekonomi, seperti mengelola kegiatan perdagangan, industri, dan pertanian (Soemitra, 2009:448).

\section{MATERI DAN METODE}

Baitul Maal Wat Tamwil (BMT) terdiri dari dua istilah, yaitu baitul maal 
dan baitut tamwil. Baitul maal lebih berorientasi pada usaha-usaha penghimpunan dan pendistribusian dana yang non-profit, seperti zakat, infaq, dan shadaqah. Sedangkan baitut tamwil sebagai usaha pengumpulan dan penyaluran dana bersifat profit. Usahausaha tersebut menjadi bagian yang tidak terpisahkan dari BMT sebagai lembaga pendukung kegiatan ekonomi masyarakat kecil dengan berlandaskan syariah (Sudarsono, 2008:103).

Baitul Maal Wat Tamwil (BMT) atau Balai Usaha Mandiri Terpadu adalah lembaga keuangan mikro yang operasionalnya menggunakan prinsip bagi hasil, menumbuh kembangkan bisnis usaha mikro dalam rangka mengangkat derajat dan martabat serta membela kepentingan kaum fakir miskin, ditumbuhkan atas prakarsa dan modal awal dari tokoh-tokoh masyarakat setempat dengan berlandaskan sistem ekonomi yang salaam: keselamatan (berintikan keadilan), kedamaian, dan kesejahteraan (Rianto Al Arif, 2012:317).

Dalam mengelola bisnisnya BMT tidak jauh berbeda dengan dengan BPR syariah, yakni menggunakan 3 prinsip: (Sudarsono, 2008:108-109).

1. Prinsip bagi hasil

Dengan prinsip ini, BMT selaku shahibul mal yang memberikan pembiayaan kepada mudharib akan memperoleh bagi hasil sesuai dengan akad yang disepakati. Beberapa pilihan akad yang digunakan diantaranya almudharabah, al-musyarakah, almuzara'ah dan al-musaqah.

2. Sistem jual beli

Sistem jual beli merupakan suatu tata cara jual beli yang dalam aplikasinya BMT menunjuk nasabah sebagai agen yang diberi kuasa melakukan pembelian barang atas nama BMT, dan kemudian bertindak sebagai penjual, dengan menjual barang yang telah dibelinya tersebut dengan ditambah mark-up. Keuntungan BMT nantinya akan dibagi kepada penyedia dana. Dengan menggunakan pilihan akad, yaitu: bai' almurabahah, bai' as-salam, bai'al-istishna dan bai' bitsaman ajil.

3. Sistem non-profit

Sistem ini sering disebut pembiayaan kebajikan yang merupakan pembiayaan bersifat sosial dan non-komersial. Nasabah cukup mengembalikan pokok pinjamannya saja. Sistem ini menggunakan akad Al-qordhul hasan.

Untuk memperlancar tugas BMT, maka diperlukan struktur yang mendeskripsikan alur kerja yang dijalankan oleh masing-masing personil BMT tersebut. Struktur organisasi BMT meliputi Musyawarah Anggota Pemegang Simpanan Pokok, Dewan Syariah, Pembina Manajemen, Manajer, Pemasaran, Kasir, dan pembukuan.

Adapun tugas dari masing-masing struktur tersebut adalah sebagai berikut:

1. Musyawarah Anggota Pemegang Simpanan Pokok memegang kekuasaan tertinggi dalam memutuskan kebijakan-kebijakan makro BMT.

2. Dewan Syariah, bertugas mengawasi dan menilai operasionalisasi BMT.

3. Pembina Manajemen, bertugas untuk membina jalannya BMT dalam merealisasikan programnya.

4. Manajer bertugas menjalankan amanat musyawarah anggota BMT dan memimpin BMT dalam merealisasikan programnya.

5. Pemasaran bertugas untuk mensosialisasikan dan mengelola produk-produk BMT.

6. Kasir bertugas melayani nasabah.

7. Pembukuan bertugas untuk melakukan pembukuan atas asset dan omzet BMT.

Tingkat kesehatan BMT merupakan suatu keadaan yang menunjukkan gambaran kinerja dan kualitas BMT, dimana dipengaruhi oleh berbagai faktor dan dapat juga mempengaruhi aktivitas serta kemampuan untuk melaksanakan 
kegiatan operasional perbankan secara normal dan mampu memenuhi semua kewajibannya dengan baik sesuai dengan peraturan perbankan yang berlaku. Tingkat kesehatan BMT dapat diukur dengan beberapa analisis rasio keuangan yang diterapkan oleh PINBUK (Pusat Inkubasi Bisnis Usaha Kecil) sebagai kriteria penilaian kesehatan BMT.

Menurut Keputusan Menteri Negara Koperasi dan Usaha Kecil dan Menengah Republik Indonesia No. 96/Kep/M.KUKM/IX/2004 tentang Pedoman Standar Operasional Manajemen Koperasi Simpan Pinjam dan Unit Simpan Pinjam Koperasi pasal 33 mengenai Pengukuran kinerja KSP/USP Koperasi sebagaimana dimaksud dalam pasal 28 menyebutkan bahwa analisis rasio yang digunakan dalam pengukuran kinerja keuangan pada koperasi meliputi rasio likuiditas, solvabilitas dan rentabilitas. Ketiga rasio tersebut meliputi :

1. Rasio Likuiditas, atau juga disebut dengan rasio modal kerja merupakan rasio yang digunakan seberapa likuidnya suatu perusahaan. Dengan kata lain, rasio likuiditas berguna untuk mengetahui kemampuan perusahaan dalam membiayai dan memenuhi kewajiban/utang pada saat ditagih atau jatuh tempo (Kasmir, 2015:145).

Jenis-jenis rasio likuiditas yang dapat digunakan oleh perusahaan yaitu :

a. Rasio Lancar (Current Ratio), rasio ini menunjukkan sejauh mana aktiva lancar menutupi kewajibankewajiban lancar (Sofyan, 2008:301)

Current Ratio $=\frac{\text { AktivaLancar }}{\text { UtangLancar }} \times 100 \%$

b. Rasio Kas (Cash Ratio), yaitu rasio yang digunakan untuk mengukur seberapa besar uang kas yang tersedia untuk membayar utang.

$$
\text { Cash Ratio }=\frac{\text { kas }+ \text { bank }}{\text { utang lancar }} \times 100 \%
$$

2. Rasio Solvabilitas. Rasio yang menggambarkan kemampuan perusahaan dalam membayar kewajiban jangka panjangnya atau kewajiban-kewajibannya apabila perusahaan dilikuidasi.

a. Total debt to total asset ratio

Rumus yang digunakan untuk menghitung Total debt tototal assetratio, yaitu

Total debt to total asset ratio= $\frac{\text { total hutang }}{\text { Total Asset }} \times 100 \%$

\section{b. Long term debt to equity ratio}

Rumus yang digunakan untuk menghitung Long term debt to equity ratio, yaitu

Long term debt to equity ratio = $\frac{\text { hutang jangka panjang }}{\text { modal sendiri }} \times 100 \%$

3. Rasio Rentabilitas, rasio ini digunakan untuk mengetahui kemampuan perusahaan dalam mencetak laba. Dalam hal ini ada dua rumus yang dapat digunakan yaitu ROA (Return On Asset) untuk mengetahui pengembalian bisnis atas seluruh investasi yang dilakukan, dan ROE (Return On Equity) digunakan untuk mengukur keberhasilan bisnis dalam "memperkaya" pem.egang saham (Jusuf, 2008:50-60).

a. Return On Asset

Rumus yang digunakan untuk menghitung return of investment adalah:

Return of asset $=\frac{\text { laba bersih }}{\text { total aktiva }} \times 100 \%$

b. Return On Equity

Rumus yang digunakan untuk menghitung return of investment adalah: 


$$
\begin{aligned}
& \text { return of investment }=\frac{\text { laba bersin }}{\text { modal sendiri }} \times \\
& 100 \%
\end{aligned}
$$

\section{Jenis Penelitian}

Penelitian ini menggunakan tipe field research atau penelitian lapangan yang berupaya mengumpulkan datadata lapangan didukung dengan berbagai informasi dan literatur yang relevan dengan permasalahan yang sedang diteliti dengan pendekatan kuantitatif. Menurut Sugiyono (2009:8) Metode kuantitatif adalah metode penelitian yang berlandaskan pada filsafat positivisme, digunakan untuk penelitian pada populasi atau sampel tertentu, pengumpulan data menggunakan instrumen penelitian, analisis data bersifat statistik. Penelitian ini diorientasikan untuk mengetahui faktor faktor yang mempengaruhi kinerja BMT.

\section{Populasi dan Sampel}

Populasi adalah sumber data dalam penelitian tertentu yang memiliki jumlah banyak dan luas. Jika data diambil dari populasi, maka akan memerlukan dana dan waktu yang cukup banyak sehingga dalam penelitian hal itu terlalu mahal. (Deni, 2013:137-138). Populasi dalam penelitian ini adalah seluruh karyawan BMT Khairu Ummah Leuwiliang yang berjumlah 27 karyawan.

Menurutut Gulo (2002:78) Sampel sering disebut juga "contoh" himpunan bagian (subset) dari suatu populasi. Sebagai bagian dari populasi, sampel memberikan gambaran yang benar tentang populasi. Pengambilan sampel dari suatu populasi disebut penarikan sampel atau sampling. Menurut Suharsimi Arikunto (2006:12), jika subjek penelitiannya kurang dari 100, maka lebih baik diambil semuanya sehingga penelitiannya penelitian populasi. Dengan demikian jumlah sampel dalam penelitian ini sesuai dengan jumlah populasi yaitu 27 orang.

\section{Sumber Data}

Sumber data pada penelitian ini, yaitu:

1. Data primer adalah data yang dapat diperoleh secara langsung dari sumber yang bersangkutan. Dalam penelitian ini, data diperoleh melalui kuesioner yang disebar kepada responden.

2. Data sekunder adalah data yang diperoleh dari hasil olahan data primer. Data sekunder berfungsi sebagai data pendukung dari data primer. Dalam penelitian ini data sekunder diambil dari jurnal, bukubuku, artikel dan literatur yang berkaitan dengan penelitian ini.

\section{Teknik Pengumpulan Data}

Untuk teknik pengambilan data, penulis menggunakan beberapa instrumen dalam penelitian sebagai berikut:

\section{Observasi}

Observasi adalah alat pengumpulan data yang dilakukan cara mengamati dan mencatat secara sistematik gejala-gejala yang diselidiki. (Narbuko dan Achmadi, 2013:70). Teknik ini mengharuskan adanya pengamatan dari penulis baik secara langsung ataupun tidak langsung terhadap objek penelitiannya. Insrumen yang dipakai dapat berupa lembar pengamatan, panduan pengamatan, dan lainnya (Umar, 2005:51).

2. Kuesioner (Angket)

Menurut Sangadji dan Sopiah (2010:193), Kuesioner merupakan metode yang dilakukan untuk mengumpulkan data dengan cara menyebarkan daftar pertanyaan kepada responden agar ia memberikan jawabannya. Kuesioner dalam penelitian ini bersifat tertutup yang jawabannya sudah disediakan sehingga responden tinggal memilih. Kuesioner yang digunakan didesain berdasarkan skala likert yang berisikan sejumlah pernyataan yang menyatakan objek yang hendak diungkap. Masing-masing kuesioner telah 
disediakan lima jawaban dengan skor sebagai berikut (Deni, 2013:264):

a. Responden yang memberikan jawaban "Sangat setuju" diberi skor 5

b. Responden yang memberikan jawaban "Setuju" diberi skor 4

c. Responden yang memberikan jawaban "Ragu-ragu" diberi skor 3

d. Responden yang memberikan jawaban "Tidak setuju" diberi skor 2

e. Responden yang memberikan jawaban "Sangat Tidak Setuju" diberi skor 1.

\section{Definisi Variabel Operasional}

a) Variabel bebas (Independen)

Menurut Rochaety (2007:11) Variabel bebas adalah variabel yang mempengaruhi variabel lain. Variabel ini merupakan variabel yang diukur, dimanipulasi atau dipilih oleh peneliti untuk menentukan hubungannya dengan suatu gejala yang diobservasikan. Variabel independen dilambangkan dengan huruf "X". Dalam penelitian ini yang menjadi variabel independen adalah pendidikan, jam kerja, manajemen, jumlah produk, gaji, dan atribut produk.

b) Variabel terikat (Dependen)

Variabel terikat disebut juga peubah respon atau outcome (hasil percobaan). Peubah bebas tersebut dimanipulasi secara langsung oleh peneliti, untuk mengkaji pengaruhnya pada satu atau lebih respon (Hendri dan Abrista, 2013:91-92). Variabel terikat dilambangkan dengan huruf "Y". Adapun variabel terikat dalam penelitian ini adalah kinerja BMT.

\section{Teknik Analisis Data}

\section{Uji Validitas dan Reliabilitas}

Menurut Suharsimi (2003:219), Uji validitas adalah kondisi yang menjelaskan tingkat instrumen yang bersangkutan mampu mengukur apa yang akan diukur. Instrumen yang valid menunjukkan bahwa instrumen tersebut dapat digunakan untuk mengukur apa yang hendak diukur secara tepat dan benar. Instrumen penelitian yang memiliki validitas tinggi, menggambarkan hasil penelitian mampu menjelaskan masalah penelitian sesuai dengan keadaan atau kejadian yang sebenarnya.

Reliabilitas adalah derajat ketepatan, ketelitian atau keakuratan yang ditunjukkan oleh instrumen pengukuran. Pengujian reliabilitas secara internal dapat dilakukan dengan cara menganalisis konsistensi butir-butir yang ada. Sedangkan secara eksternal, yaitu dengan melakukan test-retest.

\section{Regresi Linear Berganda}

Regresi dapat dikatakan linear berganda jika variasi peubah yang akan diperkirakan dijelaskan oleh variasi dari beberapa peubah, penjelas (lebih dari satu peubah jelas). Analisis ini dipilih karena penelitian ini dirancang untuk meneliti variabel bebas yang berpengaruh terhadap variabel tidak bebas. Persamaan regresi linear berganda dapat dirumuskan sebagai berikut:

$$
Y=a+b_{1} X_{1}+b_{2} X_{2}+b_{3} X_{3}+\ldots+\varepsilon
$$

$\begin{array}{ll}\text { Dimana, } & \\ \mathrm{Y} & \text { : Kinerja BMT } \\ a & : \text { Konstanta } \\ \mathrm{b}_{1}, \mathrm{~b}_{2}, & \text { : Koefisien regresi } \\ \mathrm{X}_{1} & \text { : Pendidikan } \\ \mathrm{X}_{2} & \text { : Jam kerja } \\ \mathrm{X}_{3} & \text { : Manajemen } \\ \mathrm{X}_{4} & \text { : Jumlah produk } \\ \mathrm{X}_{5} & \text { : Gaji } \\ \mathrm{X}_{6} & \text { : Atribut produk } \\ \varepsilon & : \text { Error }\end{array}$

\section{Uji Hipoesis}

Uji t (Parsial)

Analisis perbandingan suatu variabel bebas dikenal dengan uji $t$ atau

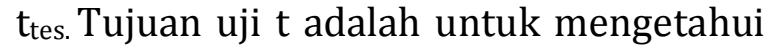
perbedaan variabel yang dihipotesiskan (Ridwan dan Sunarto,2011:116). Cara pengujian parsial terhadap variabel independen adalah sebagai berikut:

1) Jika nilai signifikansi t dari masingmasing variabel yang diperoleh dari 
pengujian lebih kecil dari nilai signifikansi yang dipergunakan yaitu sebesar $5 \% \quad(0,05)$ maka secara parsial variabel independen berpengaruh terhadap variabel dependen.

2) Jika nilai signifikansi t dari masingmasing variabel yang diperoleh dari pengujian lebih besar dari nilai signifikansi yang dipergunakan yaitu sebesar $5 \% \quad(0,05)$ maka secara parsial variabel independen tidak berpengaruh terhadap variabel dependen.

\section{Uji f (Simultan)}

Menurut Gulo (2002:203), Uji f adalah perbandingan antara jumlah seluruh variasi antar kelompok dengan jumlah seluruh variasi yang bersumber dari dala ssetiap kelompok. Analisis ini melihat apakah perbedaan rata-rata pada beberapa sampel berbeda secara signifikan atau tidak. Uji $\mathrm{F}$ digunakan untuk menguji signifikansi pengaruh variabel Xterhadap variabel $Y$ secara bersama-sama.

Kriteria penerimaan dan penolakan hipotesis adalah:

1) Jika F hitung < F table, maka Ho ditolak,

2) Jika F hitung > F table, maka Ho diterima

Berdasarkan dasar signifikansi, kriterianya adalah:

1) Jika nilai signifikansi $>0,05$ maka signifikan,

2) Jika nilai signifikansi $<0,05$ maka tidak signifikan.

\section{HASIL DAN PEMBAHASAN}

\section{Sejarah Baitul Maal Wat Tamwi (BMT) Khairu Ummah}

Baitul mal wat tamwil (BMT) merupakan lembaga yang berdiri dan diorientasikan untuk membangun dan meningkatkan tingkat ekonomi anggota pada khususnya dan masyarakat pada umumnya dan juga sebagai penguatan ekonomi rakyat serta menguatkan sumber daya manusia.

Gagasan berdirinya Koperasi Simpan Pinjam dan Pembiayaan Syari'ah (KSPPS) atau BMT Khairu Ummah berawal dari para stakeholder pondok pesantren yaitu Ir. Yuyud wahyudin, Drs. M. yusuf, Ir. Ade Hambali, Dra. Erna Jernawati dan Yusfitriadi, M.Pd pada tahun 1980-1990 yang ingin melahirkan lembaga ekonomi mikro dengan fungsi menghimpun dana iuran dan hibah yang dijadikan sebagai modal usaha, seperti sablon dan penjualan buku yang meskipun usahanya berpindah-pindah tempat. Kemudian tahun 1994 berdirilah Koperasi Pondok Pesantren (KOPONTREN) "Muallimin" atas dorongan program pemerintah yang berupaya membudayakan koperasi sebagai suatu lembaga ekonomi mikro masyarakat di pondok pesantren. Usaha KOPONTREN tersebut bergerak dalam bidang jasa pembiayaan Islam. Di tahun yang sama, usaha KOPONTREN meningkat dengan memiliki unit usaha Alat Tulis dan Kantor (ATK), unit usaha Warung Serba Ada (WASERDA) dan unit usaha Baitul mal wa tamwil (BMT) dengan Manager Pepi Januar Pelita, S.Kom. Akan tetapi, dengan berbagai pertimbangan di tahun yang sama KOPONTREN "Muallimin" tersebut memutuskan hanya berfokus pada unit usaha Baitul mal wa tamwil (BMT). Sehingga KOPONTREN "Muallimin" berganti nama menjadi Baitul mal wa tamwil (BMT) .

Pada tahun 1997-1998 terjadi krisis moneter yang mengakibatkan Baitul mal wat tamwil (BMT) tidak mampu membangun kinerja yang baik pada masyarakat sehingga pada saat itu dimungkinkan bangkrut. Akan tetapi, para penggagas koperasi pada saat itu mempercayakan dan memberikan tanggungjawab maupun mandat kepada Pepi Januar Pelita, S.Kom untuk melanjutkan Baitul mal wa tamwil (BMT) 
agar terus bertahan dan menjadi lebih baik.

Dengan penuh tanggungjawab dan rasa memiliki yang sangat tinggi pada Pepi Januar Pelita, S.Kom kinerja Baitul mal wa tamwil (BMT) terus diperbaiki baik dari segi internal maupun eksternal. Dampaknya, kinerja maupun citra Baitul mal wa tamwil (BMT) cukup membaik di kalangan masyarakat maupun pemerintah. Kemudian pada tahun 20032004 pemerintah mengeluarkan program untuk peningkatan kemandirian ekonomi rakyat dengan dana usaha $\mathrm{Rp}$ $50.000 .000,00-/$ tahun pada setiap BMT. Dana tersebut digunakan Baitul mal wa tamwil (BMT) sebagai modal agar bisa bangkit dari keterpurukan. Hasilnya, BMT semakin dapat membangun atau memelihara serta meyakinkan kepercayaan masyarakat sekitar dan mitra-mitra BMT dengan baik sehingga jumlah karyawan semakin banyak dan membantu program pemerintah dalam menyerap tenaga kerja semakin meningkat. BMT juga semakin maju dan mempunyai asset sendiri yang cukup memadai untuk unit usaha Baitul Mal dan memiliki unit usaha Baitul Tamwil (pembiayaan) di beberapa cabang yaitu cabang Leuwiliang, cabang Puraseda, cabang Cibeber Nanggung dan cabang Cigudeg.

Pada tahun 2015 Menteri Koperasi Dan Usaha Kecil Dan Menengah Republik Indonesia mengeluarkan peraturan dengan NOMOR 16/Per/M.KUKM/IX/2015 Tentang Pelaksanaan Kegiatan Usaha Simpan Pinjam dan Pembiayaan Syariah yang isinya menetapkan bahwa Koperasi Simpan Pinjam dan Pembiayaan Syariah BMT Khairu Ummah, dimana responden yang lama bekerjanya $<5$ tahun sebanyak 16 orang (59,3\%), 5-10 tahun sebanyak 10 orang (37\%) dan $>10$ tahun sebanyak 1 orang $(3,7 \%)$. Dengan demikian responden yang lama bekerjanya $<5$ tahun lebih banyak. selanjutnya disebut KSPPS adalah koperasi yang kegiatan usahanya meliputi simpanan, pinjaman dan pembiayaan sesuai prinsip syariah, termasuk mengelola zakat, infaq/sedekah, dan wakaf. Dengan peraturan tersebut, nama Baitul mal wa tamwil (BMT) berganti nama menjadi Koperasi Simpan Pinjam dan Pembiayaan Syari'ah (KSPPS) "Khairu Ummah" sampai sekarang.

\section{Karakteristik Responden}

Berdasarkan hasil penelitian yang dilakukan dari 27 karyawan di BMT Khairu Ummah, dimana yang berjenis kelamin laki-laki terdapat 21 orang $(77,8 \%)$ dan yang berjenis kelamin perempuan terdapat 6 orang $(22,2 \%)$. Dengan demikian responden laki-laki lebih banyak dibandingkan responden perempuan.

Berdasarkan hasil kuesioner dapat diketahui usia dari 27 karyawan BMT Khairu Ummah dimana untuk yang berusia $<20$ tahun sebanyak 2 orang $(7,4 \%)$, usia $20-30$ tahun yaitu 20 orang $(74,1) \%$, usia 31-40 tahun sebanyak 5 orang (18,5\%). Dengan demikian mayoritas responden yaitu berusia 20-30 tahun.

Berdasarkan hasil kuisioner dapat diketahui pendidikan terakhir dari 27 karyawan BMT Khairu Ummah, dimana karyawan lulusan Sekolah Menengah Atas (SMA) sebanyak 19 orang $(70,4 \%)$, Diploma tiga (D3) sebanyak 3 orang (11,1\%), dan Sarjana (S1) sebanyak 5 orang $(18,5 \%)$. Hal ini menunjukkan bahwa mayoritas responden berpendidikan terakhir di tingkat Sekolah Menengah Atas (SMA).

Berdasarkan hasil kuisioner dapat diketahui lama bekerja dari 27 karyawan

\section{Uji Validitas dan Realibilitas}

Uji validitas dilakukan dengan bantuan program SPSS Versi 23.0 for windows, yaitu dengan menggunakan Correcrted Item Total Correlation. Jika nilai $r$ hitung $>r$ tabel, maka dapat dinyatakan valid, tetapi jika $r$ hitung $<r$ 
tabel dinyatakan tidak valid (nilai $r$ tabel dengan responden 27 orang adalah 0,381). Dari 20 pertanyaan kuisioner menunjukkan nilai Correcrted Item Total Correlation lebih besar dari 0,381 dengan nilai Correcrted Item Total Correlation terendah adalah 0,391 pada pertanyaan kedua. Ini berarti bahwa semua pernyataan kuisioner valid dan dapat dilanjutkan untuk penelitian dan analisis lebih lanjut.

Uji reliabilitas bertujuan untuk mengukur konsisten tidaknya jawaban responden terhadap item-item pertanyaana di dalam kuesioner. Suatu kuesioner dinyatakan reliabel jika Croanbach'sAlpha $>0,60 . u j i$ reliabilitas dapat dilihat dalam tabel berikut :

\section{Tabel 1}

Hasil Uji Reliabilitas

\begin{tabular}{cc}
\hline Cronbach's Alpha & N of Items \\
0,865 & 20 \\
\hline
\end{tabular}

Sumber: Hasil Penelitian

Dari tabel diatas dapat dilihat bahwa nilai Croanbach's Alpha sebesar 0,865, maka dapat disimpulkan bahwa kuesioner dalam penelitian ini dinyatakan reliabel, karena nilai Cronbach's Alpha lebih besar dari 0,60

\section{Hasil Analisis Laporan Keuangan}

Untuk menilai kinerja BMT pihak manajemen harus mengetahui keadaan ekonomis BMT. Oleh karena itu media laporan keuangan inilah yang menjadi sarana informasi dan menjabarkan posisi keuangan BMT.

\section{a) Likuiditas}

Likuiditas merupakan kemampuan BMT untuk memenuhi kewajiban jangka pendeknya. Pemenuhan kewajiban tersebut dapat dijaminkan dengan jumlah aktiva yang dimiliki BMT.

\section{Current Rasio}

Rumus yang digunakan untuk menghitung current Rasio yaitu :

Current Ratio $=\frac{\text { AktivaLancar }}{\text { HutangLancar }} \times 100 \%$
Dari laporan keuangan yang diperoleh peneliti menunjukkan tahun 2014 rasio likuiditas BMT dilihat dari sisi Current Ratio sebesar 125,867\%, yang berarti setiap Rp 1,00 utang lancar akan dijamin sebesar $125,867 \%$, dari aktiva lancar. Tahun 2015 diperoleh Current Ratio sebesar 106,851\%, yang berarti setiap Rp 1,00 utang lancar akan dijamin sebesar 106,851\% dari aktiva lancar. Sedangkan tahun 2016 diperoleh Current Ratio sebesar 119,865\%, yang berarti setiap Rp 1,00 utang lancar akan dijamin sebesar 119,865\%, dari aktiva lancar.

\section{Cash Ratio}

Rasio ini digunakan untuk mengukur kemampuan kas yang sesungguhnya untuk memenuhi hutanghutangnya tepat pada waktunya.

Rumus yang digunakan untuk menghitung cash ratio:

Cash Ratio $=\frac{\text { kas }+ \text { bank }}{\text { Total HutangLancar }} \times 100 \%$

Bberdasarkan laporan keuangan tahun 2014 dihasilkan cash ratio sebesar 46,346\%, ini menunjukkan bahwa setiap Rp. 1,00,- hutang lancar dijamin dengan kas yang ada sebesar 46,346\% untuk memenuhi kewajibannya. Pada tahun 2015 dihasilkan rasio sebesar 39,368\%, ini menunjukkan bahwa setiap Rp. 1,00,- hutang lancar dijamin dengan kas yang ada sebesar 39,368\% untuk memenuhi kewajibannya. Pada tahun 2016 dihasilkan rasio sebesar 43,511\%, ini menunjukkan bahwa setiap Rp. 1,00,hutang lancar dijamin dengan kas yang ada sebesar 43,511\% untuk memenuhi kewajibannya.

\section{b) Solvabilitas}

1. Total debt to total asset ratio

Rumus yang digunakan untuk menghitung Total debt tototal assetratio, yaitu: 
Total debt to total asset ratio $=\frac{\text { total hutang }}{\text { Total Asset }}$ $\times 100 \%$

Tahun 2014, Debt to Total Assets Ratio sebesar 76,163\% menunjukkan bahwa setiap total utang Rp 1,00 dijamin dengan aktiva perusahaan sebesar 76,163\%. Tahun 2015 dihasilkan rasio sebesar 76,522 \% menunjukkan bahwa setiap total utang Rp 1,00 dijamin dengan aktiva perusahaan sebesar 76,522. Pada tahun 2016 Debt to Total Assets Ratio sebesar 76,683\% menunjukkan bahwa setiap total utang Rp 1,00 dijamin dengan aktiva perusahaan sebesar $76,683 \%$.

2. Long term debt to equity ratio

Rumus yang dapat digunakan untuk menghitung Long term debt to equity ratio adalah:

Long term debt to equity ratio $=$ $\frac{\text { hutang jangka panjang }}{\text { modal sendiri }} \times 100 \%$

Tahun 2014, Debt to Equity Ratio sebesar $11,265 \%$ dari rasio ini dapat dikatakan bahwa setiap Rp 1,00 utang dijamin dengan 11,265\% modal sendiri. Tahun 2015 diperoleh Debt to Equity Ratio sebesar 7,380\% yang berarti setiap Rp 1,00 utang dijamin dengan 7,380\% modal sendiri. Tahun 2016 diperoleh Debt to Equity Ratio sebesar 7,407\% yang berarti setiap Rp 1,00 utang dijamin dengan 7,407\% modal sendiri.

\section{c) Rentabilitas}

1. Return of investment

Rumus yang digunakan untuk menghitung return of investment adalah:

$\begin{aligned} & \begin{array}{l}\text { Return of investment } \\ \text { sisa hasil usaha setelah zakat }\end{array} \times 100 \% \\ & \text { total aktiva }\end{aligned}=$

Tahun 2014, Return on Investment sebesar 2,514\% berarti bahwa setiap Rp 1,00 dari total aktiva dapat digunakan untuk menghasilkan laba bersih sebesar 2,514\%. Tahun 2015 Return on Investment sebesar $4,083 \%$ berarti bahwa setiap Rp 1,00 dari total aktiva dapat digunakan untuk menghasilkan laba bersih sebesar 4,083\%. Tahun 2016 Return on Investment sebesar 1,954\% berarti bahwa setiap Rp 1,00 dari total aktiva dapat digunakan untuk menghasilkan laba bersih 1,954\%.

2. Return on equity

Rumus yang dignnaka untuk menghitung Return on equity sebagai berikut :

Return of equity =

$\frac{\text { sisa hasil usaha setelah zakat }}{\text { modal sendiri }} \times 100 \%$

Tahun 2014, Return On Equity sebesar $19,045 \%$ yang artinya bahwa setiap Rp 1,00 modal dapat mengasilkan laba bersih sebesar 19,045\%. Tahun 2015 Return On Equity sebesar 24,13\% yang artinya bahwa setiap Rp 1,00 modal dapat mengasilkan laba bersih sebesar 24,13\%. Tahun 2016 Return On Equity sebesar $11,779 \%$ yang artinya bahwa setiap Rp 1,00 modal dapat mengasilkan laba bersih sebesar 11,779\%.

\section{Analisis Regresi Linear Berganda}

Diperoleh persamaan regresi sebagai berikut :

$\mathrm{Y}=2,725+0,141 \mathrm{X} 1+0,418 \mathrm{X} 2+0,265$ $\mathrm{X} 3+0,157 \mathrm{X} 4+0,180 \mathrm{X} 5$

Persamaan regresi diatas dapat dijelaskan sebagai berikut:

- Nilai konstanta (a) adalah 2,725. Hal ini dapat diartikan jika pendidikan, jam kerja, manajemen, gaji, atribut produk bernilai 0 , maka kinerja BMT bernilai positif yaitu 2,725.

- Nilai koefisien regresi variabel pendidikan bernilai positif 0.141 . Hal ini dapat diartikan bahwa setiap peningkatan dimensi pendidikan sebesar 1\%, maka kinerja BMT akan meningkat sebesar 0.141 (dengan asusmsi variabel lain nilainya tetap).

- Nilai koefisien regresi variabel jam kerja bernilai positif 0,418 . Hal ini dapat diartikan bahwa setiap peningkatan dimensi jam kerja 
sebesar 1\%, maka kinerja BMT akan meningkat sebesar 0.418 (dengan asusmsi variabel lain nilainya tetap).

- Nilai koefisien regresi variabel manajemen bernilai positif 0,265 . Hal ini dapat diartikan bahwa setiap peningkatan dimensi manajemen sebesar 1\%, maka kinerja BMT akan meningkat sebesar 0.265 (dengan asusmsi variabel lain nilainya tetap).

- Nilai koefisien regresi variabel gaji bernilai positif 0,157 . Hal ini dapat diartikan bahwa setiap peningkatan dimensi gaji sebesar 1\%, maka kinerja BMT akan meningkat sebesar 0.157 (dengan asusmsi variabel lain nilainya tetap).

- Nilai koefisien regresi variabel attribut produk bernilai positif 0,180. Hal ini dapat diartikan bahwa setiap peningkatan dimensi atribut produk sebesar 1\%, maka kinerja BMT akan meningkat sebesar 0.180 (dengan asusmsi variabel lain nilainya tetap).

\section{Uji Hipotesis}

Uji $F$ digunakan untuk mengetahui pengaruh secara bersama-sama antara variabel independen terhadap variabel dependen. Dapat diketahui hipotesisnya sebagai berikut:

Ho : pendidikan, jam kerja, manajemen, gaji, dan atribut produk secara bersamasama tidak berpengaruh terhadap kinerja BMT.

Ha : pendidikan, jam kerja, manajemen, gaji, dan atribut produk secara bersamasama berpengaruh terhadap kinerja BMT. Dari hasil Output data kuesioner yang diolah pada IBM SPSS Statistics diketahui nilai signifikansi sebesar 0,039.

Keterangan :

- Jika signifikansi > 0,05, maka Ho diterima

- Jika signifikansi $<0,05$, maka Ho ditolak

Nilai signifikansi 0,39 $<0,05$, maka Ho ditolak. Jadi sapat disimpulkan bahwa variabel pendidikan, jam kerja, manajemen, gaji, dan atribut produk secara bersama-sama berpengaruh terhadap kinerja BMT.

Uji $\mathrm{T}$ digunakan untuk mengetahui apakah secara parsial variabel pendidikan, jam kerja, manajemen, gaji, dan atribut produk berpengaruh secara signifikan terhadap kinerja BMT. Untuk mengetahui hasilnya dapat dilihat dari kolom (sig).

Keterangan :

- Jika signifikansi > 0,05, maka Ho diterima

- Jika signifikansi $<0,05$, maka Ho ditolak

Tabel 2

Hasil Analisis Uji T

\begin{tabular}{|l|c|c|}
\hline \multicolumn{1}{|c|}{ Model } & $\mathrm{T}$ & Sig. \\
\hline (Constant) & 1,844 &, 079 \\
Pendidikan &, 621 &, 042 \\
\multirow{2}{*}{$\begin{array}{l}\text { jam kerja } \\
\text { Manajemen }\end{array}$} &, 979 &, 339 \\
Gaji &, 632 &, 026 \\
atribut produk &, 557 &, 018 \\
\hline
\end{tabular}

Sumber: Output data kuesioner yang diolah pada IBM SPSS Statistics

\section{- Pengujian koefisien variabel pendidikan (X1)}

Ho : pendidikan tidak berpengaruh signifikan terhadap kinerja BMT

Ha : pendidikan berpengaruh signifikan terhadap kinerja BMT

Dari tabel diatas dapat diketahui nilai signifikansi sebesar 0,042. Artinya $0,042<0,05$ maka Ho ditolak. Jadi dapat disimpulkan bahwa pendidikan berpengaruh signifikan terhadap kinerja BMT.

- Pengujian koefisien variabel jam kerja (X2)

Ho : jam kerja tidak berpengaruh signifikan terhadap kinerja BMT

Ha : jam kerja berpengaruh signifikan terhadap kinerja BMT

Dari tabel diatas dapat diketahui nilai signifikansi sebesar 0,026. Artinya 
0,026 > 0,05 maka Ho diterima. Jadi dapat disimpulkan bahwa jam kerja tidak berpengaruh signifikan terhadap kinerja BMT.

\section{- Pengujian koefisien variabel manajemen (X3)}

Ho : manajemen tidak berpengaruh signifikan terhadap kinerja BMT

Ha : manajemen berpengaruh signifikan terhadap kinerja BMT

Dari tabel diatas dapat diketahui nilai signifikansi sebesar 0,042. Artinya $0,042<0,05$ maka Ho ditolak. Jadi dapat disimpulkan bahwa manajemen berpengaruh signifikan terhadap kinerja BMT.

\section{- Pengujian koefisien variabel gaji} (X4)

Ho : gaji tidak berpengaruh signifikan terhadap kinerja BMT

Ha : gaji berpengaruh signifikan terhadap kinerja BMT

Dari tabel diatas dapat diketahui nilai signifikansi sebesar 0,018. Artinya $0,018<0,05$ maka Ho ditolak. Jadi dapat disimpulkan bahwa gaji berpengaruh signifikan terhadap kinerja BMT.

- Pengujian koefisien variabel atribut produk (X5)

Ho : atribut produk tidak berpengaruh signifikan terhadap kinerja BMT

$\mathrm{Ha}$ : atribut produk berpengaruh signifikan terhadap kinerja BMT

Dari tabel diatas dapat diketahui nilai signifikansi sebesar 0,038. Artinya $0,038<0,05$ maka Ho ditolak. Jadi dapat disimpulkan bahwa atribut produk berpengaruh signifikan terhadap kinerja BMT.

\section{KESIMPULAN DAN IMPLIKASI}

Berdasarkan hasil penelitian dan pembahasan, penulis menyimpulkan bahwa ada beberapa faktor yang mempengaruhi kinerja BMT, antara lain fakor pendidikan karyawan berpengaruh terhadap kinerja BMT. Hal ini dibuktikan pada analisis uji t dengan nilai signifikansi sebesar 0,042 lebih kecil dari 0.05. Faktor manajemen berpengaruh terhadap kinerja BMT, hal ini dibuktikan pada analisis uji $t$ dengan nilai signifikansi sebesar 0,026 lebih kecil dari 0.05. Faktor gaji karyawan berpengaruh terhadap kinerja BMT, hal ini dibuktikan pada analisis uji $t$ dengan nilai signifikansi sebesar 0,018 lebih kecil dari 0.05 Faktor atribut produk berpengaruh terhadap kinerja BMT, hal ini dibuktikan pada analisis uji $t$ dengan nilai signifikansi sebesar 0,038 lebih kecil dari 0.05

\section{DAFTAR PUSTAKA}

Al Arif, M.Nur Rianto. 2012. Lembaga Keuangan Syariah. CV Pustaka Setia: Bandung.

Darmawi, Herman. 2012 Manajemen Perbankan Cet.2. Bumi Aksara: Jakarta.

Harahap, Sofyan Syafri. 2008. Analisis Kritis atas Laporan Keuangan. PT RajaGrafindo Persada: Jakarta

Jusuf, Jopie. 2008. Analisis Kredit untuk Account Officer. PT Gramedia Pustaka Utama: Jakarta.

Kasmir. 2015. Analisis Laporan Keuangan. PT RajaGrafindo Persada: Jakarta.

Mardani. 2015. Aspek Hukum Lembaga Keuangan Syariah di Indonesia Cet. 1. Prenadamedia Group: Jakarta.

Muhammad. 2007. Lembaga Ekonomi Syariah, Yogyakarta: Graha Ilmu.

Ridwan, Muhammad. 2004. Manajemen Baitul Maal Wat Tamwil. UII Press: Yogyakarta.

Rodoni, Ahmad dan Abdul Hamid. 2008. Lembaga Keuangan Syariah. PT Bestari Buana Murni: Jakarta.

Sa'roni, Lia Syukriyah. 2010. Analisis Faktor-Faktor Yang Mempengaruhi Keberhasilan BMT Berkah Madani Cimanggis, Skripsi, Universitas Islam Negeri Syarif Hidayatullah Jakarta.

Sartono, Agus. 2001Manajemen Keuangan Teori dan Aplikasi, Yogyakarta: BPFE-Yogyakarta. 
Soemitra, Andri. 2009 Bank \& Lembaga Keuangan Syariah. Kencana: Jakarta.

Sriyana , Jaka. 2013. Peran BMT dalam Mengatasi Kemiskinan di Kabupaten Bantul. Inferensi, Jurnal Penelitian Sosial Keagamaan. Vol. 7: 29-50.

Sudarsono, Heri. 2008. Bank dan Lembaga keuangan Syariah. Ekonesia: Yogyakarta.

Sukmana, Adi Angga dan Sri Mulyati. 2015. Penilaian Kesehatan KJKS BMT
Binamas, Jurnal Akuntansi dan Keuangan Islam Vol. 2, No. 2: 125144.

Widaryanti. 2014. Analisis Kinerja Keuangan Dan Pengelolaan Internal Bmt (Studi Kasus Pada Bmt-Bmt Di Kota Semarang), Jurnal Dinamika Ekonomi \& Bisnis, Vol. 11, No. 1: 1331.

Yamit, Zulian. 2010. Manajemen Keuangan. Ekonisia: Yogyakarta. 